\title{
Relationship between the number of partial resistance genes and the response to leaf rust in wheat genotypes
}

\author{
Lourdes Ledesma-Ramirez ${ }^{1}$, Ernesto Solis-Moya ${ }^{1 *}$, Juan G. Ramírez-Pimentel ${ }^{2}$, Susanne Dreisigacker ${ }^{3}$, \\ Julio Huerta-Espino4 ${ }^{4}$ Cesar L. Aguirre-Mancilla², and Luis A. Mariscal-Amaro ${ }^{1}$ \\ ${ }^{1}$ Instituto Nacional de Investigaciones Forestales, Agrícolas y Pecuarias (INIFAP), Campo Experimental Bajío, km 6.5, Carr. Celaya- \\ San Miguel C. P. 38110, Celaya, Guanajuato, México. ${ }^{*}$ Corresponding author (solis.ernesto@inifap.gob.mx). \\ ${ }^{2}$ Instituto Tecnológico de Roque, km 8 Carretera Celaya-Juventino Rosas, A.P. 508, C.P. 38110, Celaya, Guanajuato, México. \\ ${ }^{3}$ Centro Internacional de Mejoramiento de Maíz y Trigo (CIMMYT), km 45, Carr. México-Veracruz, El Batán, C.P. 56237, Texcoco, \\ Estado de México, México. \\ ${ }^{4}$ Instituto Nacional de Investigaciones Forestales, Agrícolas y Pecuarias (INIFAP), Campo Experimental Valle de México, A.P. No. 10, \\ C.P. 56230, Chapingo, Estado de México, México.
}

Received: 2 March 2018; Accepted: 3 July 2018; doi:10.4067/S0718-58392018000300400

\begin{abstract}
The adult plant resistance conferred by genes with an additive effect is an alternative to achieve durable resistance to leaf rust caused by the fungus Puccinia triticina in wheat (Triticum spp.) The objective of this study was to know the response to this disease in bread wheat genotypes that possess the partial resistance genes $\operatorname{Lr} 34, L r 46, L r 67$ and $L r 68$. The severity level of the disease was measured in 280 wheat genotypes in three locations. The presence or absence of partial resistance genes was determined by molecular markers for each gene in 245 wheat genotypes. The different combinations of adult plant genes resulted in the genotypes were classified into nine groups. In 77 of these genotypes, the markers were negative for these genes. The $\operatorname{Lr} 34, \operatorname{Lr} 46, \operatorname{Lr} 67$ and $\operatorname{Lr} 68$ genes were identified individually in 48, 48, 5, and 14 genotypes, respectively. The combination of two genes, Lr34+Lr46, Lr34+Lr68 and Lr46+Lr68, was determined in 18, 17, and 12 genotypes, respectively. Only in six genotypes the combination $L r 34+L r 46+L r 68$ was identified. The genotypes with the $L r 34, L r 46$, Lr67 and $\operatorname{Lr68}$ genes in a unique form showed 21\%,24.8\%,21.9\% and 21.8\% of rust severity on average, respectively. An additive effect was observed in the combinations of two genes, and higher effect in the combinations that included the Lr34 gene since genotypes with this gene combination showed on average $11.4 \%$ of rust severity. The combination of three genes $L r 34+L r 46+L r 68$ provide greater protection in the genotypes with $9.7 \%$ of rust severity on average.
\end{abstract}

Key words: Adult plant resistance, phenotype, severity, slow-rusting, Triticum aestivum.

\section{INTRODUCTION}

To date, more than 77 leaf rust resistance genes have been formally designated (McIntosh et al., 2017) in wheat (Triticum aestivum L.) Most of these genes confer race-specific resistance, which is characterized with qualitative inheritance, hypersensitive reactions and gene-for-gene interaction between host and pathogen (Johnson, 1981). The race specific resistance is easily overcome with the emergence of new virulent races. In contrast, only few genes are slow-rusting adult plant resistance (APR) type that is expressed in the post-seedling growth stages by significantly delaying the epidemic process with reduced growth and reproduction of the pathogen (Caldwell, 1968; Singh et al., 2005). 
The partial resistance of slow-rusting to leaf rust caused by the fungus Puccinia triticina Erikss., also called quantitative or race non-specific adult-plant resistance, has been classified as durable type (Huerta et. al., 2004). According to Huerta et al. (2004) varieties of wheat with this type of resistance, such as 'Rayón F89' and 'Salamanca S75', have been planted for more than 20 years in different wheat producing regions in Mexico. The genes that confer partial resistance are also characterized by their additive effect, both with other partial resistance genes (Singh and Rajaram, 1992), and specific resistance genes (German and Kolmer, 1992). Of the leaf rust resistance genes reported, only Lr34, Lr46, Lr67 and Lr68 confer partial resistance (Herrera et al., 2011).

The Lr34 gene was first described in the cv. Frontana in 1966 (Dyck et al., 1966) and is located on the short arm of chromosome 7D. The resistance displayed by this gene includes a longer latency period and a smaller number and size of uredinia. Lagudah et al. (2006) developed a sequence-tagged site (STS) marker, csLV34, which was mapped to $0.4 \mathrm{cM}$ of the $\operatorname{Lr34}$ gene and which has been validated in many lines and varieties of different breeding programs of the world (Kolmer et al., 2008). Singh and Huerta (1997) studied the effect of the Lr34 gene in $\mathrm{F}_{6}$ inbred lines, and their results showed that the lines with $\operatorname{Lr} 34$ registered 50\% severity with losses of $15 \%$ in yield, while the lines without the gene showed $100 \%$ severity and yield losses up to $84 \%$.

The Lr46 gene was reported in 'Pavón 76' and was located on chromosome 1B (Singh et al., 1998; William et al., 2003). Singh et al. (1998) pointed out that the $L r 46$ gene did not provide sufficient protection against leaf rust when the intensity of the disease was high since the percentage of severity in genotypes with only this gene reached up to $60 \%$. On the other hand, Kolmer (2015) showed that $\mathrm{F}_{6}$ inbred lines with the Lr46 gene, identified with the csLV46 marker, expressed an average severity of $35 \%$.

The Lr67 gene was identified in line PI250413 and was transferred to 'Thatcher' through backcrossing Thatcher * 6/PI250413 = RL6077. Phenotypic expression of Lr67 gene is similar to Lr34 since it could also be associated with resistance to linear rust (Puccinia striiformis f. sp. tritici) (Herrera et al., 2011) and stem rust (Puccinia graminis f. sp. tritici) (Herrera et al., 2014). Field evaluations conducted by Herrera et al. (2011) showed that Lr67 confers lower resistance than the $\operatorname{Lr} 34$.

The origin of the Lr68 gene could be 'Frontana' (Herrera et al., 2012). The cs7BLNLRR marker produces a fragment of $738 \mathrm{bp}$ in the presence of $L r 68$, and two bands of 478 and $270 \mathrm{bp}$ in genotypes without Lr68 (Herrera et al., 2012). It has been observed in field tests that the lines carrying the $L r 68$ gene have lower leaf rust severity compared with the susceptible controls; however, the effect of the Lr68 gene is less than that provided by the Lr34, Lr46 and Lr67 genes (Herrera et al., 2012).

The prominent slow-rusting APR genes identified in bread wheat linked to leaf tip necrosis (Ltn) (Herrera et al., 2012) are Lr34/Yr18 (Singh, 1992), Lr46/Yr29 (William et al., 2003), Lr67/Yr46 (Herrera et al., 2011) and Lr68 (Herrera et al., 2012). However, other adult plant resistance genes have been recently identified in winter wheat such as $\operatorname{Lr} 74$ ( $\mathrm{Li}$ et al., 2017), $\operatorname{Lr} 75$ not associated with the Ltn (Singla et al., 2017) and $L r 77$ (Kolmer et al., 2018) have been identified in winter wheat accessions. An additional adult plant resistance gene $(L r 78)$ was identified in cv. Toropi (Kolmer et al., 2017). $L r 77$ had a very similar severity and response compared to lines with the adult plant resistance gene $L r 78$, derived from 'Toropi' (Kolmer et al., 2017). According to Kolmer et al. (2018) $L r 77$ had more effective resistance manifested by distinct necrosis and chlorosis compared to Thatcher lines with the adult plant resistance genes $\operatorname{Lr} 34, \operatorname{Lr} 46$, and $\operatorname{Lr} 67$ in field plot tests. With the exception of 'Toropi', the effectiveness of the resistance genes from the winter wheat onto the spring environments and backgrounds remain to be tested.

Most of the leaf rust adult plant resistance genes cited and identified in the spring wheats might be present in the Mexican varieties released from 1950 to present including in the study either single or in combinations. It is expected that cultivars with more adult plant resistance genes show less disease severities in the field compared to those lacking one or more of these resistance genes.

The objective of this study was to study the relationship between the number of partial resistance genes to leaf rust and the phenotypic response in wheat genotypes measured in percentage of disease severity. With the hypothesis that genotypes with a greater number of partial resistance genes have a lower disease severity in field tests. 


\section{MATERIALS AND METHODS}

The study was conducted in two stages, in determination of the phenotypic resistance to leaf rust of 280 genotypes; and determination of the leaf rust resistance genes of the adult plant.

\section{Determination of leaf rust resistance of genotypes}

The phenotypic evaluation of leaf rust resistance was carried out in 280 wheat genotypes, of which 245 were bread wheat (Triticum aestivum L.) and 35 crystalline wheat (T. durum Desf.). The experiment was established in the Spring-Summer 2013 and 2014 cycles (CPV13 and CPV14), in the Bajío Experimental Field of the Instituto Nacional de Investigaciones Forestales, Agrícolas y Pecuarias (INIFAP), Celaya (20³2' N, $100^{\circ} 48^{\prime} \mathrm{W}$; $1752 \mathrm{~m}$ a.s.l.), México, with precipitation and average annual temperature of $578 \mathrm{~mm}$ and $19.8^{\circ} \mathrm{C}$. In the fall-winter 2013-2014 cycle (SON13) the experiment was established at the Norman E. Borlaug Experimental Field (CENEB) ( $32^{\circ} 18^{\prime} \mathrm{N}, 115^{\circ} 4^{\prime} \mathrm{W} ; 37 \mathrm{~m}$ a.s. 1 .) The characteristic climate of the area where the CENEB is located presents precipitation values and average annual temperature of $277 \mathrm{~mm}$ and $31.0^{\circ} \mathrm{C}$, respectively.

The design used in the three environments (cycles) was an alpha lattice with two replicates and 14 sub-blocks. The experimental plot was a two-wire furrow of $1 \mathrm{~m}$, planted at a density of $120 \mathrm{~kg}$ seed ha $\mathrm{a}^{-1}$. Management of the plots was performed following the INIFAP guidelines in each location. In Guanajuato, plots were fertilized with 180-60-00 of ammonium sulfate $(878 \mathrm{~kg}$ ) and calcium triple superphosphate $(130 \mathrm{~kg})$, applying all $\mathrm{P}$ and half $\mathrm{N}$ at the time of sowing and the other half of $\mathrm{N}$ at $35 \mathrm{~d}$ after sowing; in Sonora, plots were fertilized with 240-60-00 of ammonium sulfate (1170 $\mathrm{kg}$ ) and calcium triple superphosphate $(130 \mathrm{~kg})$ using the same fractionation scheme as in Guanajuato. In CPV13 the sowing irrigation was given and an irrigation of aid at $50 \mathrm{~d}$ after the first, in CPV14 three irrigations were applied, the sowing irrigation and two of aid at 35 and $75 \mathrm{~d}$ after sowing. In Sonora (SON13) five irrigations were applied at 0, 41, 68, 89 , and $104 \mathrm{~d}$ after sowing.

Experimental plots were separated by $1 \mathrm{~m}$ alleys. In these alleys the susceptible 'Morocco' was planted. The 'Morocco' plants were inoculated with a suspension of uredospores $\left(1 \times 10^{6}\right.$ uredospores $\left.\mathrm{mL}^{-1}\right)$ of the MCJ/SP and MBJ/SP leaf rust races four times to generate the epiphyte following the standard CIMMYT methodology (Lan et al., 2014). Rust severity ratings were taken according to the modified Cobb scale (Peterson et al., 1948). The percentage of final severity of the genotypes was considered when 'Morocco' and other susceptible varieties such as 'Yecora 70' reached 100\% rust severity according to the scale. Statistical analysis severity data were transformed to arcosene using the formula: arc sinus $\sqrt{ } \mathrm{x} / 100$ in the Excel program. Then, ANOVA of the three locations with the transformed data was carried out using the SAS software version 9.3 (SAS Institute, Cary, North Carolina, USA). The rust severity means of each genotype in the three environments were estimated and grouped according to the number of adult plant genes using molecular markers as reference. Comparisons between groups were made through orthogonal contrasts. Analysis of the genotype by environment interaction was performed with the AMMI1 model using the SAS software version 9.3.

\section{Determination of the partial resistance genes (GRP)}

The presence of GRP or non-specific race genes, Lr34, Lr46, Lr67, and Lr68 were determined only in bread wheats with AABBDD genome using the following methodology: DNA was extracted from 245 genotypes of bread wheat following the protocol of Saghai et al. (1984). PCR reactions were performed in a final volume of $25 \mu \mathrm{L}$ including $50 \mathrm{ng}$ genomic DNA, $25 \mathrm{mM}$ dNTP (Roche) concentration, $1 \mu \mathrm{L}$ each primer (LGC Genomics and Sigma-Aldrich, St. Louis, Missouri,

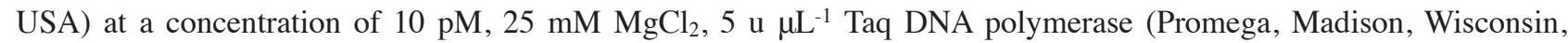
USA). The different $L r$ genes detected, chromosomal location, name and sequence of the primers, $\mathrm{T}^{\circ}$ of mating, source of resistance and reference of origin are detailed in Table 1. Polymerase chain reaction (PCR) products were visualized in $14 \%$ polyacrylamide gel electrophoresis (PAGE; Sigma-Aldrich). Gels were stained with silver nitrate, stain was removed, and documented with digital photography.

For markers CSLV46G22 for Lr34, CSLV46 for Lr46, CsLV67+csLV1 and BLNRR for Lr68, digestion was performed with the restriction enzymes BspEI, BSA, and HAE III (New England BioLabs, Ipswich, Massachusetts, and Takara Bio, Shiga, Japan), respectively. Reactions were incubated at $37^{\circ} \mathrm{C} \times 1 \mathrm{~h}$. Digestions were observed in $14 \%$ of polyacrylamide gels as described previously (CIMMYT, 2006). 
Table 1. Characteristics and sequence of the primers used to identify the genes $L r 34, L r 46, L r 67$, and $L r 68$.

\begin{tabular}{lclllll}
\hline Gen & Chromosome & \multicolumn{1}{c}{ Marker } & \multicolumn{1}{c}{ Primers sequence } & TM $\left({ }^{\circ} \mathrm{C}\right)$ & Source & \multicolumn{1}{c}{ References } \\
\hline Lr34 & 7D & CSLV34 + Lr34sp & 5' GTT GGT TAA GAC TGG TGA TGG-3' & 55 & Frontana & Lagudah et al. (2006) \\
Lr46 & 1BL & CSLV46G22 or CSLV46 & Not published & 56 & Pavón 76 & Singh et al. (1998) \\
Lr67 & 4D & CsLV67+csLV1 & Not published & 50 & RL6077 & Herrera et al. (2011) \\
Lr68 & 7BL & BLNLRR & 5' GAA GGA GTG CTT CCT CCA CTG-3' & 50 & Parula & Lillemo et al. (2011) \\
& & & 5'CTT GGT TCT CCT GTT CTT CCC-3' & & & \\
\hline
\end{tabular}

TM: Temperature of mating.

\section{RESULTS AND DISCUSSION}

The ANOVA for leaf rust severity detected highly significant differences between localities and varieties. There was also a Locality $\times$ Variety interaction (Table 2). Most of the variation observed between varieties was due to the wide-high genetic amplitude of resistance of the genotypes included in this study.

The AMMI model indicated the significance $(\mathrm{P}<0.01)$ of two main components that explained $57.3 \%$ and $42.6 \%$ of the sum of squares (SC) of the interaction, respectively. The model retained $72.3 \%$ of the total sum of squares (SCT) (environment + genotype + interaction) using 561 degrees of freedom ( 2 for environments, 279 for genotypes and 280 for interaction). The study of the interaction made with AMMI was completed with the use of the biplot (Figure 1).

The 'Gabo' and 'Mayo 52' recorded the highest levels of leaf rust severity through localities with averages above 70\%. In contrast, bread wheat 'Conasist F2015' and 'Oasis F86' and the durum cultivars 'Sawali Oro C2008' and 'Patronato Oro $\mathrm{C} 2008$ ' recorded values of $1 \%$ and were among the most resistant. The first two varieties based their resistance to MCJ/SP and MBJ/SP rust races on Lr24 and Lr19 respectively (Singh, 1991), whereas most Mexican durum cultivars are resistant to bread wheat leaf rust isolates due to physiological specialization of the leaf rust population from durum wheat (Huerta et al., 2014). These genotypes had consistent resistance in the three environments evaluated. The percentage of genotypes that obtained severity values lower than the mean was $58.6 \%$.

The environments (cycles) of Sonora (SON13) and Celaya (CPV14) obtained values of leaf rust severity significantly equal to $20.8 \%$ and $21.3 \%$, respectively, and lower than those observed in Celaya in the CPV13 with 27.2\% (Tukey 0.05). The genotypes 35 and 85 together with the environments of SON13 and CPV14 were the ones that contributed most to the first axis of the interaction (higher values of the main component 1) being more unstable (Figure 1). The environments CPV13 and CPV14 presented an angle of 45 degrees between them, so they classified the genotypes in a similar way (high correlation between environments). On the other hand, the angle close to $90^{\circ}$ between the environments of Guanajuato and Sonora indicates that they classified the genotypes differently (low correlation between environments), which was to be expected due to the temperature differences of the fall-winter and spring-summer cycles. The lines that connect the environment markers with the origin of the biplot are called ambient vectors. The correlation coefficient is equivalent to the cosine of the angle between two ambient vectors. The angles $<15^{\circ}$ have a very high positive correlation $(\geq 0.97)$, angles $\leq 30^{\circ}, 45^{\circ}$ and $135^{\circ}$ have high correlations and means $\geq 0.87$ and \pm 0.77 . While, the angles between vectors $\geq 150^{\circ}$ and $\geq 165^{\circ}$ present high and very high negative correlations (Gniazdowski, 2013).

Table 2. ANOVA for rust severity of $\mathbf{2 8 0}$ genotypes evaluated in three locations during the cycles Fall-Winter 2012-2013 in Sonora and Spring-Summer 2013 and 2014 in Guanajuato.

\begin{tabular}{lrrrrr}
\hline FV & GL & \multicolumn{1}{c}{ SC } & CM & FCal & Pr $>$ F \\
\hline Loc & 2 & 8661 & 4330 & 80.1 & 0.0001 \\
Rep & 1 & 310 & 310 & 5.7 & 0.0169 \\
BLO(Rep) & 110 & 6971 & 63 & 1.2 & 0.1250 \\
VARIE & 279 & 201886 & 724 & 13.4 & 0.0001 \\
Loc $\times$ VARIE & 558 & 84851 & 152 & 2.8 & 0.0001 \\
Error & 729 & 39436 & 54 & & \\
Total & 1679 & 382810 & & & \\
CV & 25.3 & & & & \\
\hline
\end{tabular}

FV: Source of variation; GL: degrees of freedom; SC: sum of squares; CM: mean squares; Fcal: F calculated, CV: coefficient of variation; Loc: location; VARIE: variety. 
Figure 1. Biplot of the genotype environment interaction of 280 wheat genotypes evaluated in three environments during the Fall-Winter 2012-2013 cycles in Sonora and Spring-Summer 2013 and 2014 in Guanajuato, Mexico.

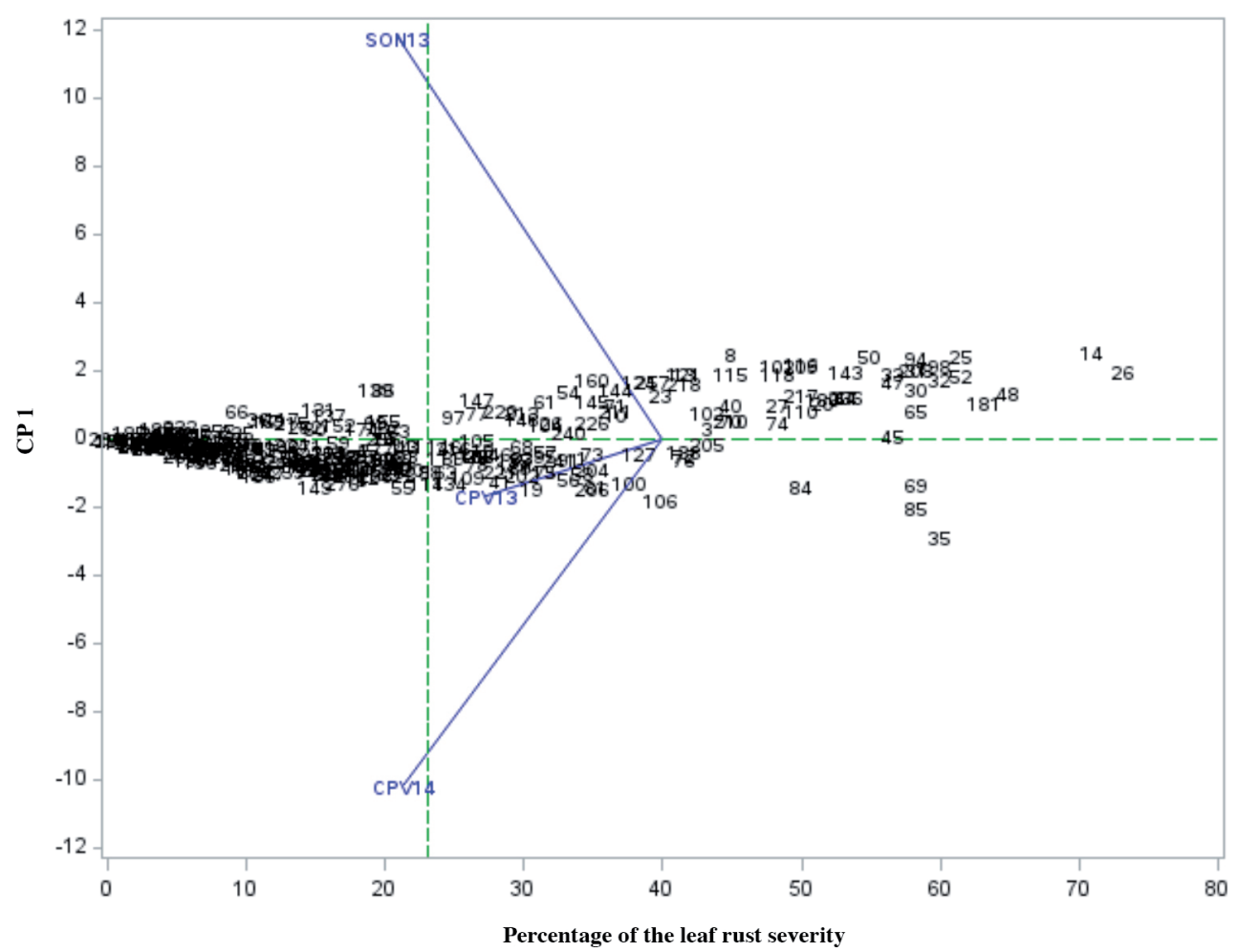

All markers amplified the expected patterns, thus allowing identify the positive genotypes for a single marker, or combinations of two or three markers of the respective resistance genes and it was also possible to discriminate those negative genotypes for the four markers used. The different combinations of adult plant genes resulted in nine groups: 1) Without genes of adult plant, the group was composed of 77 genotypes, among them varieties released at the beginning of breeding in Mexico such as 'Yaqui 48', 'Candeal 48', 'May 52' and genotypes released in the mid-80s like 'Saturno S86' and 'Pápago M86'. 2) Genotypes with the $L 34$ gene composed of 48 entries including the 'Lerma Rojo' varieties, and the first semidwarf varieties released in Mexico, 'Pénjamo T62' and 'Pitic T62'.3) Group with the Lr46 gene in a single form consisted of 48 genotypes standing out the 'Siete Cerros T66' and 'Gálvez M87' released for rainfed environments in Mexico. 4) Lr67 gene was only detected in the ancient varieties 'Chapingo 48', 'Yaqui 50', 'Yaqui 53', 'Chapingo 53' and 'Constitución', in all cases in a unique way. 5) Group with the Lr68 gene was made up of 14 genotypes, among them 'Mexico M82', 'Tacupeto F2002', and 'Monarca F2007'. The combinations of two genes identified in the bread wheat genotypes evaluated were three $L r 34+L r 46, L r 34+L r 68$ and $L r 46+L r 68$. 6) Combination $L r 34+L r 46$ was the most frequent with 18 genotypes, among them 'Kentana 48', 'Nainari 60' and varieties released at the beginning of the $21^{\text {st }}$ century as 'Juchi F2000', 'Nahuatl F2000' and 'Triunfo F2004' stand out. 7) Seventeen genotypes were identified with the combination $L r 34+L r 68$; this group was integrated among others by 'Tóbari F66', 'Nana F2007' and 'Josecha F2007'. 8) Combination of the $L r 46+L r 68$ genes was the least frequent with only 12 genotypes and it was composed, among others, by the varieties 'Arandas F90', 'Tarachi F2000', 'Roelfs F2007' and 'Villa Juárez F2009'. Genotypes with the gene combinations $\operatorname{Lr} 34+\operatorname{Lr67}, \operatorname{Lr} 46+\operatorname{Lr} 67$ and $L r 67+\operatorname{Lr} 68$ were not identified. 9) Combination of genes $\operatorname{Lr} 34+\operatorname{Lr} 46+\operatorname{Lr} 68$ was determined in the genotypes 'Bajío 52', 'Maya 74', 'Mahome F81', 'Urbina S2007', 'Norteña F2007' and the line TJB368/BUC//CUPE/4/BOW/PRL//BUC/3/TMT/5/WBLL1*2/TUKURU.

A reduction of 30.7 to 9.7 in the percentage of leaf rust severity was observed as the number of adult plant genes increased (Figure 2). This reduction in disease levels can be attributed to the additive effect of two or more adult plant resistance genes documented by Singh et al. (2011) and Singh et al. (2005). The combined effect of these genes reduces the infection percentages caused by leaf rust by decreasing the size and number of pustules, the frequency of infection and the latency period (Ellis et al., 2014). 
Figure 2. Averages of leaf rust severity based on the number of adult plant genes.

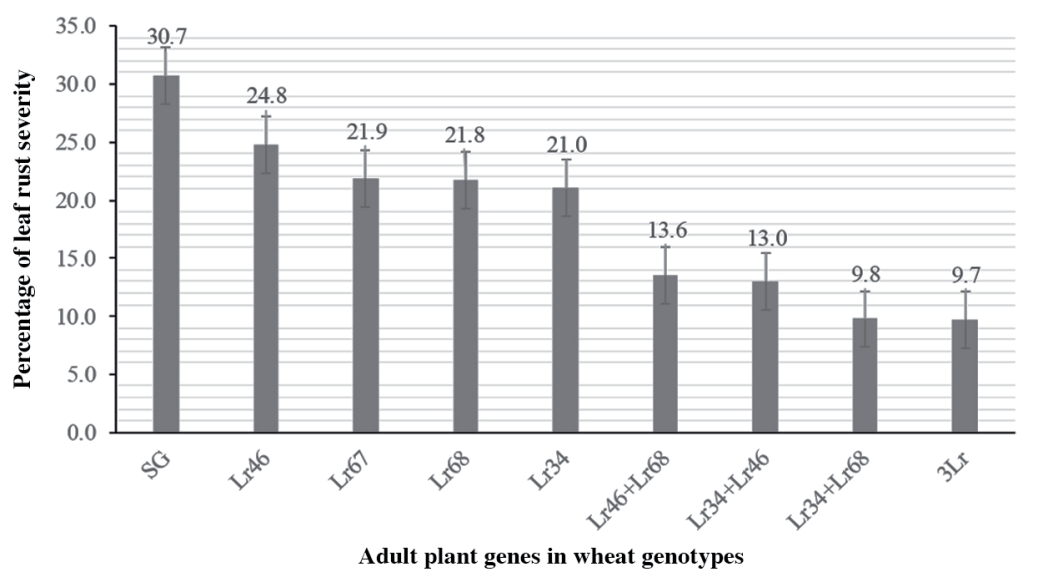

SG: Without genes or negative for any of the four markers.

\section{Contrasts between resistance groups}

Genotypes with absence of one, two or all markers evaluated in this study had higher disease severity under the conditions evaluated. Adult plant resistance is polygenic in nature and is controlled by genes of minor effect that prevent a rapid advance of the rust because they can influence factors such as frequency of infection and latency period (Riaz et al., 2016).

Lr34 gen had an effect lower than Lr46 (P $\leq 0.01$ ) (Table 3). Similarly, Lillemo et al. (2007; 2008) showed that Lr34 gene has a lower effect of resistance that $L r 46$. On the other hand, Herrera et al. (2012) when evaluating these genes in seedlings found that this gene has a defense reaction higher that $\operatorname{Lr} 46$.

Lr34 and Lr67 have similar characteristics since both confer resistance of adult plant to leaf rust (P. triticina), linear yellow rust (P. striiformis f. sp. tritici) and powdery mildew (Blumeria graminis f. sp. tritici); both are linked to genes that cause leaf tip necrosis (Spielmeyer et al., 2013). Some studies indicate that the resistance conferred by the Lr34 gene is higher than that induced by Lr67 (Hiebert et al., 2010), while others mention that the resistance provided by these genes is similar (Spielmeyer et al., 2013), which coincides with the results obtained in this study.

The effect of the $L r 68$ gene was the same as that of the $L r 34,46$ and 67 genes (Table 3). Herrera et al. (2012) pointed out that the effect of the adult plant resistance gene $\operatorname{Lr} 68$ is smaller than that of the $L r 34$ and 67 genes; however, it can be stronger than that of $L r 46$ at low temperatures.

\section{Comparisons of two or three genes}

Genotypes with combinations of two genes $L r 34+L r 46, L r 34+68$ and $L r 46+68$ exhibited higher $(\mathrm{P} \leq 0.01)$ levels of resistance than germplasm with a single gene (Table 3); however, they did not show significant differences between them. The additive nature of the adult plant genes to leaf rust and yellow rust was pointed out by Singh et al. (2000), who reported that three to five genes are necessary to achieve near immunity for these diseases. However, Dyck et al. (1966)

Table 3. Comparison of leaf rust severity averages based on the number of adult plant resistance genes.

\begin{tabular}{lcccc}
\hline Comparisons & Rust severity in percentage & Differences & Significance \\
\hline SG vs. Lr46 & 30.7 & 24.8 & 5.9 & $* *$ \\
Lr46 vs. Lr34 & 24.8 & 21.0 & 3.8 & $* *$ \\
Lr46 vs. Lr67 & 24.8 & 21.9 & 2.9 & $\mathrm{~ns}$ \\
Lr46 vs. Lr68 & 24.8 & 21.8 & 3.0 & $\mathrm{~ns}$ \\
Lr34 vs. Lr46+Lr68 & 21.0 & 13.6 & 7.4 & $* *$ \\
Lr46+Lr68 vs. Lr34+Lr46 & 13.6 & 13.0 & 0.6 & $\mathrm{~ns}$ \\
Lr46+Lr68 vs. Lr34+Lr68 & 13.6 & 9.8 & 3.8 & $\mathrm{~ns}$ \\
Lr46+Lr68 vs. Lr34+Lr46+Lr68 & 13.6 & 9.7 & 3.9 & $\mathrm{~ns}$ \\
\hline
\end{tabular}

SG: Without genes; **highly significant differences; ns: nonsignificant differences. 
reported a very weak additive effect in the combination $L r 34+L r 67$. Similar results were obtained by Lillemo et al. (2008) when pyramiding $L r 34+L r 46$, they indicate that these results are due to the fact that their resistance mechanisms are very similar, since both confer partial resistance increasing the latency period and decreasing the frequency of infection and the size of uredia.

The combination of three genes $L r 34+L r 46+L r 68$ did not provide higher protection to leaf rust (nonsignificant differences) than the combinations of two genes obtaining a severity value very similar to that recorded by the combination Lr34+Lr68.

The presence of adult plant resistance genes to leaf rust in the evaluated wheat genotypes caused less rust damage (Figure 2 and Table 3). An adult plant resistance gene provided additional protection from 19.8\% to 31.6\%, two genes from $55.7 \%$ to $68.1 \%$, and three genes $68.4 \%$.

The genotypes with $L r 46$ in a unique form present greater resistance than those that lack this type of genes, their effect is the same as that of $\operatorname{Lr} 67$ and $\operatorname{Lr} 68$ and lower than $\operatorname{Lr34}$, their interaction with other genes result in less protection (although nonsignificant) than the combination of Lr34 and Lr68.

There is a possibility that other already identified and no identified resistance genes are present in the evaluated panel, both race-specific and non-race specific which can make difficult the interpretation of the effect of adult plant resistance genes. Among the known race specific genes $\operatorname{Lr} 2 a, \operatorname{Lr} 2 c, \operatorname{Lr} 16, \operatorname{Lr} 19$, and $\operatorname{Lr} 24$ effective against the leaf rust races used in the study (Huerta et al., 2011a) will reduce the disease severity significantly in the absence of any adult plant resistance gene. On the other hand, there is the possibility that other non-identified adult plant resistance genes present in the panel with small to large effect and different from those identified with the molecular markers that greatly reduced the disease severity in both cases with the presence of other adult plant resistance genes and with or without race-specific resistance genes.

The panel used in the study include most varieties released in Mexico since 1948 to present. This resistance is the backbone of the Mexican germplasm and the spring wheat of the world (Huerta et al., 2011b). Results show the presence of the $L r 34, L r 46, L r 67$ and $L r 68$ associated with leaf tip necrosis (Ltn) and durable resistance no possible to distinguish them before the availability of molecular markers.

\section{CONCLUSIONS}

The presence of the four adult plant genes for resistance to leaf rust ( $\operatorname{Lr} 34, \operatorname{Lr} 46, \operatorname{Lr} 67$ and $\operatorname{Lr} 68$ ) was identified in the evaluated germplasm. The negative group to the presence of adult plant resistance genes was the highest with $27.5 \%$. The presence of at least one gene provides higher tolerance to rust in relation to genotypes that lack this type of genes. The effect of $L r 34$ was greater than that of $L r 46$ and equal to that of $L r 67$ and $L r 68$. An additive effect of the genes was observed in combinations of two and three adult plant genes.

\section{ACKNOWLEDGEMENTS}

We thank INIFAP for financing this research with project Nr SIGI8422632063.

\section{REFERENCES}

Caldwell, R.M. 1968. Breeding for general and/or specific plant disease resistance. In Finlay, K.W., and Shepherd, K.W. (eds.) p. 263-272. Proceedings of the Third International Wheat Genetics Symposium. Australian Academy of Sciences, Canberra, Australia.

CIMMYT. 2006. Protocolos de laboratorio de genética molecular aplicada del CIMMYT. $3^{\text {a }}$ ed. 91 p. Centro Internacional de Mejoramiento de Maíz y Trigo (CIMMYT), México, D.F.

Dyck, P.L., Samborski, D.J., and Anderson, R.G. 1966. Inheritance of adult-plant leaf rust resistance derived from the common wheat varieties exchange and Frontana. Canadian Journal of Genetics and Cytology 8:665-671. doi.org/10.1139/g66-082.

Ellis, J.G., Lagudah, E.S., Spielmeyer, W., and Dodds, P.N. 2014. The past, present and future of breeding rust resistant wheat. Front Plant Science 5:641. doi:10.3389/fpls.2014.00641.

German, S.E., and Kolmer, J.A. 1992. Effect of gene Lr34 in the enhancement of resistance to leaf rust of wheat. Theoretical and Applied Genetics 84(1-2):97-105. doi:10.1007/BF00223987. 
Gniazdowski, Z. 2013. Geometric interpretation of a correlation. Zeszyty Naukowe Warszawskiej Wyzszej Szkoly Informatyki 7(9):27-35. http://zeszyty-naukowe.wwsi.edu.pl/zeszyty/zeszyt9/Geometric_interpretation_of_a_correlation.pdf.

Herrera, F.S., Lagudah, E.S., Huerta, E.J., Hayden, M.J., Bariana, H.S., Singh, D., et al. 2011. New slow-rusting leaf rust and stripe rust resistance genes $\operatorname{Lr} 67$ and $\mathrm{Yr} 46$ in wheat are pleiotropic or closely linked. Theoretical and Applied Genetics 122(1):239-249. doi:10.1007/s00122-010-1439-x.

Herrera, F.S., Singh, R.P., Huerta, E.J., Rosewarne, G.M., Periyannan, S.K., Viccar, L., et al. 2012. Lr68: a new gene conferring slow rusting resistance to leaf rust in wheat. Theoretical and Applied Genetics 124(8):1475-1486. doi:10.1007/s00122-012-1802-1.

Herrera, F.S., Singh, R.P., Lillemo, M., Huerta, E.J., Bhavani, S., Singh, S., et al. 2014. Lr67/Yr46 confers adult plant resistance to stem rust and powdery mildew in wheat. Theoretical and Applied Genetics 127(4):781-789. doi: $10.1007 / \mathrm{s} 00122-013-2256-9$

Hiebert, C.W., Thomas, J.B., McCallum, B.D., Humphreys, D.G., DePauw, R.M., Hayden, M.J., et al. 2010. An introgression on wheat chromosome 4DL in RL6077 (Thatcher*6/PI 250413) confers adult plant resistance to stripe rust and leaf rust (Lr67). Theoretical and Applied Genetics 121(6):1083-1091. doi:10.1007/s00122-010-1373-y.

Huerta, E.J., Singh, R.P., Espitia, R.E., Villaseñor, M.E., y Leyva, M.S.G. 2004. Herencia de la resistencia a roya de la hoja en variedades de trigo para temporal. Revista Fitotecnia Mexicana 27(4):391-398.

Huerta, E.J., Singh, R.P., Germán, S., McCallum, B.D., Park, R.F., et al. 2011a. Global status of wheat leaf rust caused by Puccinia triticina. Euphytica 179(1):143-160. doi:10.1007/s10681-011-0361-x.

Huerta, E.J., Singh, R.P., and Roelfs, A.P. 2014. Rusts fungi of wheat. p. 217-259. In Misra, J.K., Tewari, J.P., Deshmukh, S.K., and Vágvölgyi, C. (eds.) Fungi from different substrates. CRC Press, Taylor \& Francis Group, Boca Ratón, Florida, USA.

Huerta, E.J., Villaseñor, M.E.H., Espitia, R.E., Solis, M.E., and Van Ginkel, M. 2011b. The history of wheat breeding in México. p. 275-308. In Bonjean, A.P., Angus, W.J., and Van Ginkel, M. (eds.) The World Wheat Book Volume 2: A History of Wheat Breeding. Lavoisier Publishing, Paris, France.

Johnson, R. 1981. Durable resistance: definition, genetic control, and attainment in plant breeding. Phytopathology 71:567-568. doi:10.1094/Phyto-71-567.

Kolmer, J.A. 2015. A QTL on chromosome 5BL in wheat enhances leaf rust resistance of Lr46. Molecular Breeding 35:74. doi:10.1007/s11032-015-0274-9.

Kolmer, J.A., Bernardo, A., Bai, G., Hayden, M.J., and Chao, S. 2017. Adult plant resistance derived from Toropi wheat is conditioned by $L r 78$ and three minor QTL. Phytopathology 108(2):246-253. doi:10.1094/PHYTO-07-17-0254-R.

Kolmer, J.A., Singh, R.P., Garvin, D.F., Viccars, L., William, H.M., Huerta, E.J., et al. 2008. Analysis of the Lr34/Yr18 rust resistance region in wheat germplasm. Crop Science 48:1841-1852. doi:10.2135/cropsci2007.08.0474.

Kolmer, J.A., Su, Z., Bernardo, A., Bai, G., and Chao, S. 2018. Mapping and characterization of the new adult plant leaf rust resistance gene $\operatorname{Lr} 77$ derived from Santa Fe winter wheat. Theoretical and Applied Genetics 131(7):1553-1560. doi:10.1007/s00122-018-3097-3.

Lagudah, E.S., McFadden, H., Singh, R.P., Huerta, E.J., Bariana, H.S., and Spielmeyer, W. 2006. Molecular genetic characterization of the $\mathrm{Lr} 34 / \mathrm{Yr} 18$ slow rusting resistance gene region in wheat. Theoretical and Applied Genetics 114(1):2130. doi:10.1007/s00122-006-0406-Z.

Lan, C.X., Singh, R.P., Calvo, S.V., Herrera, F.S.A., and Huerta, E.J. 2014. Genetic analysis of resistance to leaf rust and stripe rust in wheat cultivar Fracolin\#1. Plant Disease 98(9):1227-1234. http://dx.doi.org/10.1094/PDIS-07-13-0707-RE.

Li, C., Wang, Z., Li, C., Bowden, R., Bai, G., Li, C., et al. 2017. Mapping of quantitative trait loci for leaf rust resistance in the wheat population Ning7840 × Clark. Plant Disease 101(12):1974-1979. https://doi.org/10.1094/PDIS-12-16-1743-RE .

Lillemo, M., Asalf, B., Singh, R.P., Huerta, E.J., Chen, X.M., He,Z.H., et al. 2008. The adult plant rust resistance loci $L r 34 / Y r 18$ and $L r 46 / Y r 29$ are important determinants of partial resistance to powdery mildew in bread wheat line Saar. Theoretical and Applied Genetics 116(8):1155-1166. doi:10.1007/s00122-008-0743-1.

Lillemo, M., Singh, R.P., Huerta, E.J., Chen, X.M., He, Z.H., and Brown, J.K.M. 2007. Leaf rust resistance gene Lr34 is involved in powdery mildew resistance of CIMMYT bread wheat line Saar. p. 97-102. In Buck, H.T., Nisi, J.E., Salomón, N. (eds.) Developments in plant breeding. Wheat productions in stressed environments. Proceedings of the $7^{\text {th }}$ International Wheat Conference Mar del Plata, Argentina. 27 November-2 December 2005. Springer Netherlands, Dordrecht. The Netherlands.

Lillemo, M., Singh, R.P., William, M., Herrera, F.S.A., Huerta, E.J., German, S., et al. 2011. Multiple rust resistance and gene additivity in wheat: lessons from multi-location case studies in the cultivars Parula and Saar. p. 111-120. Borlang Global Rust Initiative (BGRI) 2011 Technical Workshop, St. Paul. 13-16 June. BGRI, Ithaca, New York, USA.

McIntosh, R.A., Dubcovsky, J., Rogers, W.J., Morris, C., and Xia, X.C. 2017. Catalogue of gene symbols for wheat: 2017 (supplement). Available at http://www.wheat.pw.usda.gov/GG2/pubs.shtml (accessed February 2018).

Peterson, R.F., Campbell, A.B., and Hannah, A.E. 1948. A diagrammatic scale for estimating rust intensity of leaves and stems of cereals. Canadian Journal of Research Section 26c(5):496-500. https://doi.org/10.1139/cjr48c-033.

Riaz, A., Periyannan, S., Aitken, E., and Hickey, L. 2016. A rapid phenotyping method for adult plant resistance to leaf rust in wheat. Plant Methods 12:17. doi:10.1186/s13007-016-0117-7. 
Saghai, M.M.A., Soliman, K.M., Jorgensen, R.A., and Allard, R.W. 1984. Ribosomal DNA spacer-length polymorphisms in barley: Mendelian inheritance, chromosomal location, and population dynamics. Proceedings of the National Academy of Sciences of the United States of America 81(24):8014-8018.

Singh, R.P. 1991. Pathogenicity variations of Puccinia recondita f. sp. tritici and $P$. graminis f. sp. tritici in wheat-growing areas of Mexico during 1988 and 1989. Plant Disease 75:790-794. doi:10.1094/PD-75-0790.

Singh, R.P. 1992. Association between gene Lr34 for leaf rust resistance and leaf tip necrosis in wheat. Crop Science 32(4):874878. doi:10.2135/cropsci1992.0011183X00320004000.

Singh, R.P., and Huerta, E.J. 1997. Effect of leaf rust resistance gene Lr34 on grain yield and agronomic traits of spring wheat. Crop Science 37(2):390-395. doi:10.2135/cropsci1997.0011183X003700020014x.

Singh, R.P., Huerta, E.J., Bhavani, S., Herrera, F.S.A., Singh, D., Singh, P.K. et al. 2011. Race non-specific resistance to rust diseases in CIMMYT spring wheats. Euphytica 179(1):175-186. doi:10.1007/s10681-010-0322-9.

Singh, R.P., Huerta, E.J., and Rajaram, S. 2000. Achieving near-immunity to leaf and stripe rust in wheat by combining slow rusting resistance genes. Acta Phytopathologica et Entomologica Hungarica 35:133-139.

Singh, R.P., Huerta, E.J., and William, H.M. 2005. Genetics and breeding for durable resistance to leaf and strip rusts in wheat. Turkish Journal of Agriculture and Forestry 29(2):121-127.

Singh, R.P., Mujeeb, K.A., and Huerta, E.J. 1998. Lr46: A gene conferring slow-rusting resistance to leaf rust in wheat. Phytopathology 88(9):890-894. doi:10.1094/PHYTO.1998.88.9.890.

Singh, R.P., and Rajaram, S. 1992. Genetics of adult-plant resistance to leaf rust in 'Frontana' and three CIMMYT wheats. Genome 35(1):24-31. doi.org/10.1139/g92-004.

Singla, J., Lüthi, L., Wicker, T., Bansai, U., Krattinger, S.G., and Keller, B. 2017. Characterization of Lr75: a partial, broadspectrum leaf rust resistance gene in wheat. Theoretical and Applied Genetics 130(1):1-12. doi:10.1007/s00122-016-2784-1.

Spielmeyer, W., Mago, R., Wellings, C., and Ayliffe, M. 2013. Lr67 and Lr34 rust resistance genes have much in common - they confer broad spectrum resistance to multiple pathogens in wheat. BMC Plant Biology 13:96. doi.org/10.1186/1471-2229-13-96.

William, M., Singh, R.P., Huerta, E.J., Ortiz, I.S., and Hoisington, D. 2003. Molecular marker mapping of leaf rust resistance gene Lr46 and its association with stripe rust resistance gene $\operatorname{Yr} 29$ in wheat. Phytopathology 93(2):153-159. doi:10.1094/PHYTO.2003.93.2.153. 